\title{
GRAIN GROWTH AND YIELD OF WHEAT AS INFLUENCED BY VARIETY AND SOWING DATE
}

\author{
R. Uddin ${ }^{1}$, M. S. Islam² ${ }^{\star}$, M. J. Ullah ${ }^{2}$ and P. K. Hore ${ }^{2}$ and S. K. Paul ${ }^{4}$ \\ ${ }^{1}$ RARS, BARI, Rahmatpur \\ ${ }^{2}$ Department of Agronomy, Sher-e-Bangla Agricultural University, Dhaka \\ ${ }^{3}$ Agronomy division, BARI, Joydebpur, Gazipur \\ *Corresponding Author: msislamsau@yahoo.com
}

Key words: Wheat variety, sowing date, grain growth, yield

\begin{abstract}
A field experiment was conducted at the Agronomy field, Sher-e-Bangla Agricultural University, Dhaka during November 2012 to April 2013 to evaluate the influence of variety and sowing date on grain growth and yield of wheat. The experiment consisted of four wheat variety viz., BARI Gom-21, BARI Gom-24, BARI Gom-25 and BARI Gom-26 and three sowing date viz., 20 November, 01December and 12 December. Grain growth, yield contributing characters and yield of wheat were significantly influenced by different variety and sowing date. Among the variety, BARI Gom-24 and BARI Gom-25 showed initial lower lag phase duration of 8 days after anthesis (DAA) and 12 DAA, respectively than BARI Gom-21 (16 DAA) sown at 01 December. The maximum grain growth rate whole over the period was maintained by BARI Gom-26 sown at 01 December. It reached peak at 20 DAA (1.17 $\mathrm{mg}$ /grain/day). The minimum growth rate was maintained by BARI Gom-21 and BARI Gom-24 sown at 12 December ( $0.15 \mathrm{mg} / \mathrm{grain} /$ day). BARI Gom-25 sown at 01December gave the highest yield $\left(4.6 \mathrm{t} \mathrm{ha}^{-1}\right)$ whereas BARI Gom-21 sown at 20 November gave the lowest $\left(2.67 \mathrm{t} \mathrm{ha}^{-1}\right)$. All the wheat varieties sown at 01 December yielded better than 20 November and 12 December sowing.
\end{abstract}

\section{Introduction}

Wheat (Triticum aestivum $\mathrm{L}$ ) is an important cereal grain crop in Bangladesh as well as in the world. It ranks first globally and second most important cereal next to rice in Bangladesh in terms of production and acreage (BBS, 2013; FAO, 2009). Estimated land, on which wheat is cultivated in Bangladesh, is 358 thousand hectare and average yield is $2780 \mathrm{~kg}$ $\mathrm{ha}^{-1}$ (AIS 2013). Wheat is one of the winter season crops in Bangladesh. Winter is becoming shorter due to climate change. Therefore, wheat production may be affected. Wheat requires different temperatures at different stages of plant growth and development. Temperature requirement may slightly differ from one variety to another. However, the optimum temperature required for wheat is $20^{\circ}$ to $25^{\circ} \mathrm{C}$ and the maximum temperature is $35^{\circ} \mathrm{C}$. If temperature is more than $30^{\circ} \mathrm{C}$ at the time of maturity, it leads to force maturity and yield loss.

The optimum temperature for wheat anthesis and grain filling ranges from 12 to $22 \circ \mathrm{C}$. Exposure to temperatures above this can significantly reduce grain yield (Tewolde et al., 2006; Fisher, 2007). Post-anthesis heat stress in wheat induces several physiological effect which eventually result in smaller grain weight due to reduced grain filling period and starch synthesis duration or the combined effect of both (Hasan and Ahmed 2005). The annual mean temperature of Bangladesh is $25.75^{\circ} \mathrm{C}$, which is expected to rise about $0.21^{\circ} \mathrm{C}$ by 2050 (Karmakar and Shrestha, 2000). The Organization for Economic Co-operation and Development (OECD) (2003) estimated arise in temperature of $1.4^{\circ} \mathrm{C}$ by 2050 and $2.4^{\circ} \mathrm{C}$ by 
Uddin et al.

2100 in Bangladesh. Islam (2009) estimated from 34 meteorological climate sites in Bangladesh, that temperature increases over the past 100 years or all Bangladesh of $0.62^{\circ} \mathrm{C}$ (maximum) and $1.54^{\circ} \mathrm{C}$ (minimum) occurred in February. Poulton and Rawson (2011) reported that temperature in Bangladesh increased over the past two decades by $0.035^{\circ} \mathrm{C} /$ year. If this trend continues, temperatures will have increased $2.13^{\circ} \mathrm{C}$ more than 1990 levels by 2050 . The rising temperature effect of global warming by crop modeling and simulation technique revealed that the warming is already slowing yield gains as a majority of wheat growing locations. Global wheat production is estimated to fall by $6 \%$ for each ${ }^{0} \mathrm{C}$ for further temperature increase and become more variable over space and time (Assenge et al. 2015).

Identification of wheat genotypes suitable for heat stress condition would be an important step for achieving high yield potential of wheat. The information is very limited regarding grain growth of wheat under different temperature. Therefore, the investigation was done to observe the grain growth rate and yield of wheat varieties sowing at different dates.

\section{Materials and Methods}

The experiment was conducted at the Agronomy farm, Sher-e-Bangla Agricultural University, Dhaka-1207 during November 2012 to April 2013. The soil was silty clay loam having low organic matter $(0.78 \%)$ and slightly acidic soil $(\mathrm{pH} 5.6)$. The location of the site was $23^{\circ} 74^{\prime} \mathrm{N}$ latitude and $90^{\circ} 35^{\prime} \mathrm{E}$ longitude with an elevation of 8.2 meter from sea level. The experiment consisted of two factors of variety and sowing date. The wheat variety viz., BARI Gom-21 $\left(\mathrm{V}_{1}\right)$, BARI Gom-24 $\left(\mathrm{V}_{2}\right)$, BARI Gom-25 $\left(\mathrm{V}_{3}\right)$ and BARI Gom-26 $\left(\mathrm{V}_{4}\right)$ and sowing date viz., 20 November $\left(\mathrm{S}_{1}\right)$, 01 December $\left(\mathrm{S}_{2}\right)$ and 12 December $\left(\mathrm{S}_{3}\right)$ were arranged in RCB design with three replications. The unit plot size was $3 \mathrm{~m} \times 2 \mathrm{~m}$. The land was prepared by ploughing and cross-ploughing with the power tiller followed by laddering uniformly. Seed was treated with vitavex@3g/kg seed. The crop was fertilized with 120-30-90-15-3-1 kg NPKSZnB ha ${ }^{-1}$ (FRG, 2012). Data on grain growth, yield contributing characters and yield were recorded. For grain growth study, three ears were harvested from each plot after anthesis at four days interval. It was continued up to 24 days after anthesis (DAA). The harvested ears were oven dried at 70 ${ }^{\circ} \mathrm{C}$ for 72 hours. Twenty grains of each genotype were separated from the middle of each spike and then weight was taken. Collected data were statistically analyzed by MSTAT-C. The treatment means were compared by the Least Significant Difference (LSD) test at 5\% level (Gomez and Gomez, 1984).

\section{Results and Discussion}

\section{Grain growth as influenced by variety and sowing date}

Grain growth rate of four wheat variety grown under different sowing dates were varied remarkably (Fig. 2). Initially the grain growth of wheat had a lag phase due to low dry matter accumulation. Among the variety, BARI Gom-21 maintained maximum duration in lag phase (16 DAA) for three sowing date. Initial lag phase duration mean temperature was ranged from $12.7-24.5^{\circ} \mathrm{C}$ whereas the rapid linear phase mean temperature was ranged from 16.7$27.5^{\circ} \mathrm{C}$ and for terminal lag phase the mean temperature was ranged from $19.9-31.6^{\circ} \mathrm{C}$. BARI Gom-24 and BARI Gom-25 sowing at different dates maintained minimum duration in lag phase (8 DAA). In BARI Gom-26, lag phase for 20 November and 12 December sowing was up to 8 DAA, but 01 December sowing maintained higher grain growth rate than others. After the completion of lag phase grain growth of four wheat variety increased rapidly. Among the different sowing dates, 01 December sowing maintained higher grain growth rate in all over the grain filling period. It might be due to prevailing optimum temperature (Fig. 2). Grain growth rate reached peak at 20 DAA. The maximum growth rate was observed in 
99

Grain Growth and Yield of Wheat as Influenced by Variety and Sowing Date

BARI Gom-26 sown at 01 December $(1.17 \mathrm{mg} / \mathrm{grain} /$ day) and the minimum was observed in BARI Gom-21 ( $0.15 \mathrm{mg} / \mathrm{grain} /$ day). The maximum grain growth of BARI Gom-26 sown at 01 December indicated that the variety was more capable to accumulate dry matter in grain than others. Karim et al. (2000) supported that grain growth pattern indicates that both higher growth rate and longer growth duration in heat tolerant wheat are responsible for its higher grain yield under late sowing conditions.

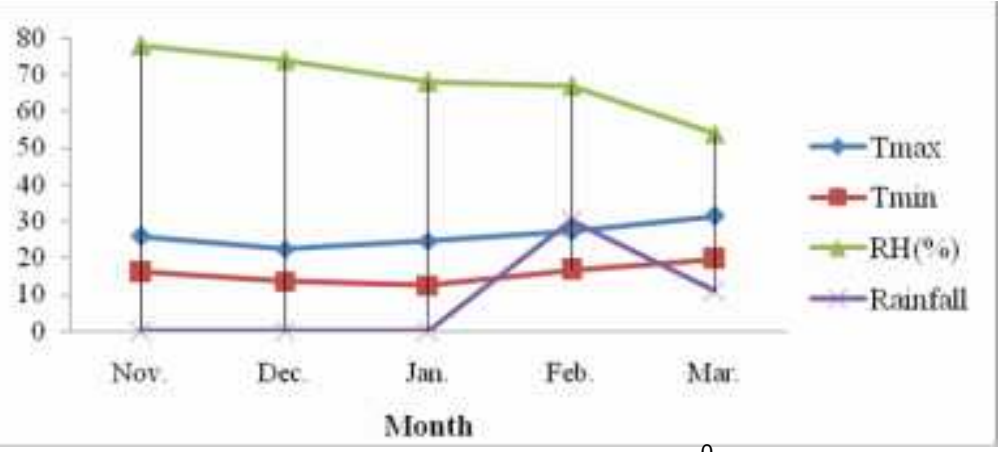

Fig 1 . Monthly mean temperature (max. and $\min .{ }^{0} \mathrm{C}$, relative humidity $(\%)$ and rainfall $(\mathrm{cm})$ during the cropping season
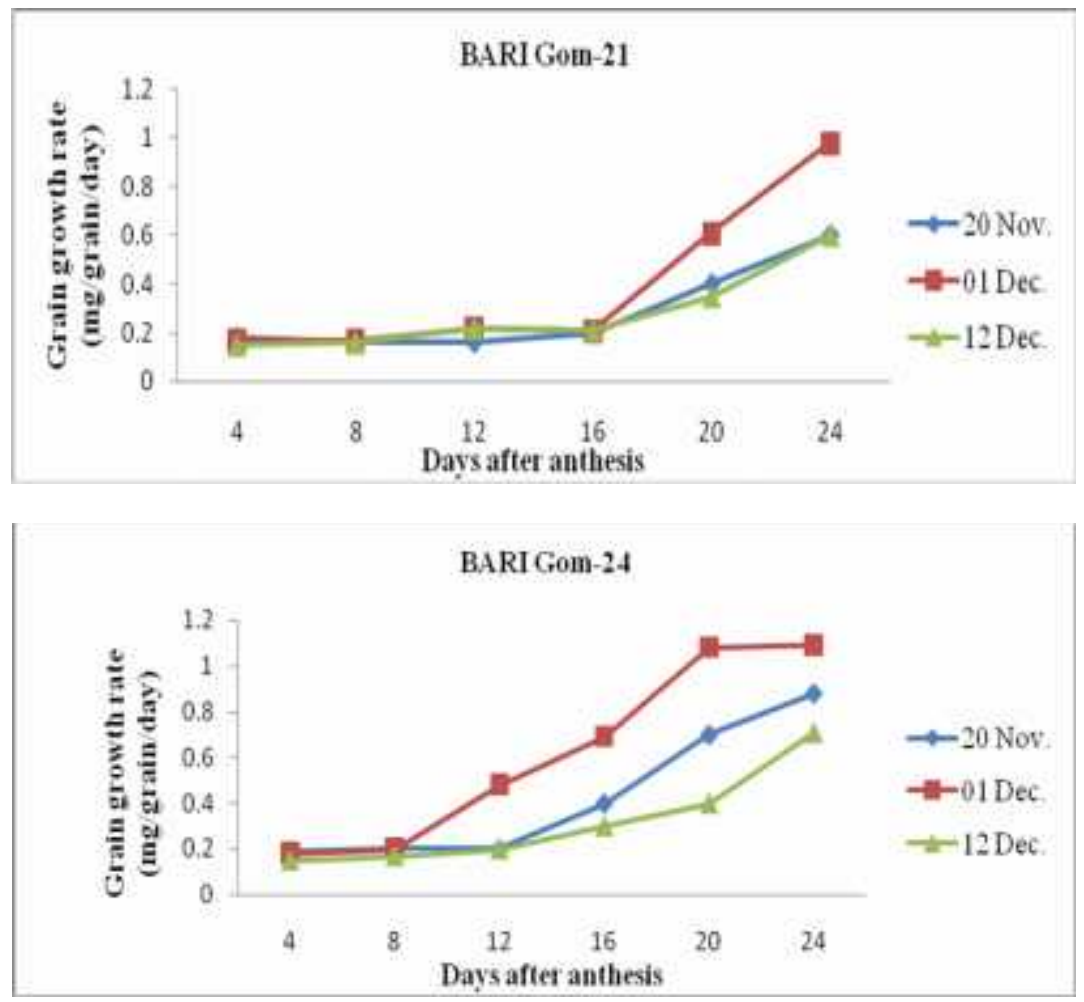
Uddin et al.
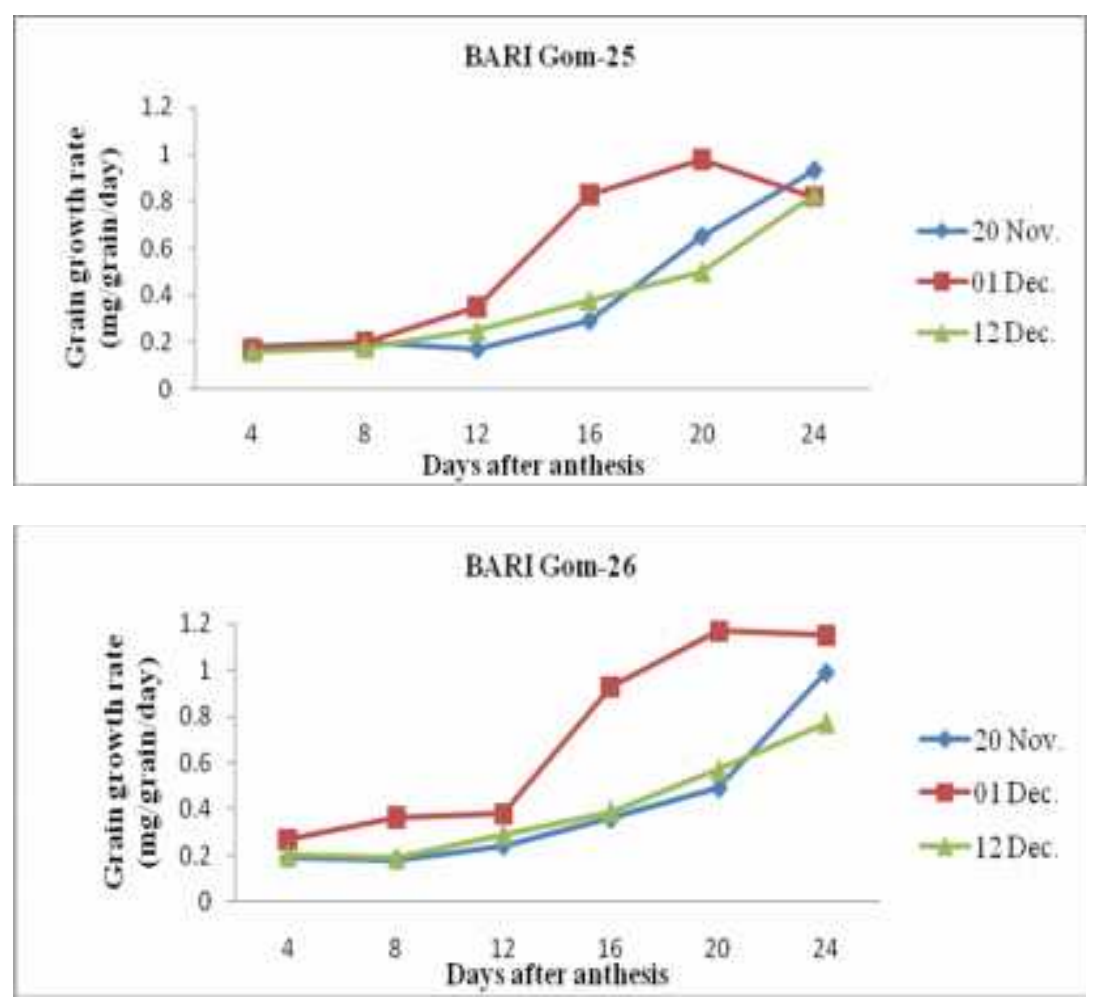

Fig 2. Grain growth rate of wheat varieties at different DAA as influenced by sowing dates

The grain growth results of this study was also supported by Karim et al. (2000) regarding wheat grain growth.

\section{Effect of variety}

Plant characters of wheat varieties were significantly differed (Table 1). The maximum number of days to reached anthesis was recorded in BARI Gom-21 (74 days) and the minimum was in BARI Gom-25 (71 days). BARI Gom-21 required maximum days to reach anthesis because its crop duration is about 120-125 days. BARI Gom-21 significantly produced the tallest plant $(89.74 \mathrm{~cm})$ while the shortest was BARI Gom-26 $(85.49 \mathrm{~cm})$. Table 1. shows that wheat variety exhibited significant variations in number of total spike $\mathrm{m}^{-2}$ (215.6 to 243.1), grain number spike ${ }^{-1}$ (37.56 to 40.37), and 1000- grain weight ( 36.67 to $40.91 \mathrm{~g}$ ). Number of total spike $\mathrm{m}^{-2}$ exhibited narrow differences among the varieties. BARI Gom- 21 produced the lighter grain and BARI Gom-24 and BARI Gom-25 produced the heavier grain. But the grain yield of wheat was not significantly differed by variety. It might be due to narrow differences in yield contributing characters. The variations in yield contributing characters of wheat due to variety were also observed by Tahir et al. (2009) and Stone et al. (1995).

\section{Effect of sowing date}

Plant characters and yield were significantly differed by sowing dates (Table 2). The crop sown at 12 December had longer vegetative phase (77 days) and shorter reproductive phase. The plant sown at 20 November showed the tallest height $(90.23 \mathrm{~cm})$ with minimum number of spike per unit area $\left(210 \mathrm{~m}^{-2}\right)$. The heavier grain weight $(42.58 \mathrm{~g})$ and number of 
Grain Growth and Yield of Wheat as Influenced by Variety and Sowing Date

grain per spike (42) were produced by 01 December sowing. Grain yield had significantly differed by sowing date. The highest grain yield was obtained from 01 December sowing $\left(4.36 \mathrm{t} \mathrm{ha}^{-1}\right)$ and the lowest from 20 November sowing $\left(3.00 \mathrm{t} \mathrm{ha}^{-1}\right)$. The variations in yield and yield contributing characters of wheat due to sowing date were also observed by Gul et al. (2012) and Fisher (2007).

Table 1. Effect of variety on plant characters, yield contributing characters and grain yield of wheat

\begin{tabular}{|c|c|c|c|c|c|c|}
\hline Variety & $\begin{array}{l}\text { Days to } \\
\text { anthesis }\end{array}$ & $\begin{array}{c}\text { Plant } \\
\text { height }(\mathrm{cm})\end{array}$ & $\begin{array}{c}\text { Grain spike-1 } \\
\text { (no.) }\end{array}$ & $\begin{array}{l}\text { Spike } \mathrm{m}^{-2} \\
\text { (no.) }\end{array}$ & $\begin{array}{c}1000 \text { grain } \\
\text { wt. (g) }\end{array}$ & $\begin{array}{c}\text { Grain yield } \\
\left(\mathrm{t} \mathrm{ha}^{-1}\right)\end{array}$ \\
\hline BARI Gom-21 & 74.33 & 89.74 & 40.11 & 226.4 & 36.67 & 3.35 \\
\hline BARI Gom-24 & 73.00 & 85.91 & 40.37 & 216.4 & 40.91 & 3.58 \\
\hline BARI Gom-25 & 71.33 & 87.03 & 37.56 & 234.6 & 40.34 & 3.57 \\
\hline BARI Gom-26 & 72.22 & 85.49 & 39.81 & 213.0 & 39.69 & 3.41 \\
\hline $\operatorname{LSD}_{(0.05)}$ & 1.02 & 0.99 & 2.01 & 12.36 & 2.79 & NS \\
\hline CV (\%) & 1.44 & 1.17 & 5.20 & 5.68 & 7.24 & 7.94 \\
\hline
\end{tabular}

Table 2. Effect of sowing date on plant characters, yield contributing characters and grain yield of wheat

\begin{tabular}{lcccccc}
\hline $\begin{array}{l}\text { Sowing } \\
\text { date }\end{array}$ & $\begin{array}{c}\text { Days to } \\
\text { anthesis }\end{array}$ & $\begin{array}{c}\text { Plant } \\
\text { height }(\mathrm{cm})\end{array}$ & $\begin{array}{c}\text { Grain spike }^{-1} \\
\text { (no.) }\end{array}$ & $\begin{array}{c}\text { Spike } \mathrm{m}^{-2} \\
\text { (no.) }\end{array}$ & $\begin{array}{c}1000 \\
\text { grain wt. } \\
(\mathrm{g})\end{array}$ & $\begin{array}{c}\text { Grain yield } \\
\left.\text { (t ha }{ }^{-1}\right)\end{array}$ \\
\hline $20 \mathrm{Nov}$ & 69.33 & 90.23 & 38.19 & 209.6 & 37.58 & 3.00 \\
$01 \mathrm{Dec}$ & 71.67 & 86.52 & 42.36 & 242.7 & 42.58 & 4.36 \\
$12 \mathrm{Dec}$ & 77.17 & 84.38 & 37.83 & 215.6 & 38.04 & 3.08 \\
\hline $\mathrm{LSD}_{(0.05)}$ & 0.89 & 0.86 & 1.74 & 10.70 & 2.41 & 0.23 \\
$\mathrm{CV}(\%)$ & 1.44 & 1.17 & 5.20 & 5.68 & 7.24 & 7.94 \\
\hline
\end{tabular}

\section{Interaction effects of variety and sowing date}

Plant characters, yield contributing characters and grain yield were significantly differed by the interaction effects of variety and sowing date (Table 3 ). The maximum number of days to anthesis (79 days) was recorded in BARI Gom-24 sown at 12 December and the minimum from BARI Gom-25 sown at 20 November (67 days). BARI Gom-21 sown at 20 November showed the tallest plant $(92.27 \mathrm{~cm})$ while BARI Gom-24 sown at 01 December showed the shortest $(82.40 \mathrm{~cm})$. The highest number of spike was obtained from BARI Gom-21 sown at 20 November $\left(263 \mathrm{~m}^{-2}\right)$ and the lowest obtained from the same variety sown at 20 November $\left(190 \mathrm{~m}^{-2}\right)$. BARI Gom-26 sown at 01 December produced the highest 1000-grain weight $(43.83 \mathrm{~g})$ while BARI Gom-25 sown at 12 December produced the lowest $(34.87 \mathrm{~g})$. The maximum number of grain per spike (45) was recorded in BARI Gom-26 sown at 01 December and the minimum from BARI Gom-25 sown at 20 November (34 spike ${ }^{-1}$ ). The highest grain yield $\left(4.61 \mathrm{t} \mathrm{ha}^{-1}\right)$ was obtained from BARI Gom-25 sown at 01 December which was identical with the grain yield obtained from BARI Gom-26 $\left(4.53 \mathrm{t} \mathrm{ha}^{-1}\right)$ and BARI Gom-21 (4.16 tha $\left.{ }^{-1}\right)$ sown at the same date. The grain growth rate of BARI Gom-25 and BARI Gom-26 showed the shorter initial lag phase duration sown on 01 December than the other sowing dates and the grain filling duration continued after 24 DAA where it faced terminal heat stress and switched to terminal lag phase (Fig. 2). The maximum grain filling occurred at the optimum temperature $\left(16.6-27.5^{\circ} \mathrm{C}\right)$ and maximum kernel mass was gained (Fig. 1). Hossain et al. (2012) supported the result that all wheat varieties, when sown late, faced severe temperature stress that significantly affected phenology, growth and finally yield. Taking into consideration phenological variation, dry matter (fresh and dry weight) 
Uddin et al.

partitioning and grain yield, variety 'BARI Gom-26' performed better both in optimum and late heat stress, followed by 'BARI Gom-25'; 'Gourab' performed the least. The lowest yield was recorded from BARI Gom-26 sown at 20 November $\left(2.60 \mathrm{t} \mathrm{ha}^{-1}\right)$. From the fig. 2 this is apparent that the longer initial lag phase duration of BARI Gom-26 sown at 20 November had lower grain growth rate. Moreover, the rapid linear phase did not exhibit the sigmoid pattern and showed decreased kernel mass production than the other sowing dates. From the $20 \mathrm{DAA}$, it started to enhance the grain growth rate where it faced the terminal heat stress $\left(19.9-31.6^{\circ} \mathrm{C}\right)$ (Fig. 1) mostly and this may be resulted in shorter grain filling period. Stone et al. (1995) supported the result that reductions in mature kernel mass resulted primarily from reductions in duration rather than rate of grain filling. The previous findings of Gupta et al. (2010), Qasim et al. (2008), Gul et al. (2012) and Shirpurkar et al. (2007) in various wheat were also supported these results.

Table 3. Interaction effects of variety and sowing date on plant characters, yield contributing characters and grain yield of wheat

\begin{tabular}{|c|c|c|c|c|c|c|}
\hline Treatments & $\begin{array}{l}\text { Days to } \\
\text { anthesis }\end{array}$ & $\begin{array}{l}\text { Plant height } \\
(\mathrm{cm})\end{array}$ & $\begin{array}{c}\text { Grain spike } \\
{ }_{\text {(no.) }}\end{array}$ & $\begin{array}{l}\text { Spike } \mathrm{m}^{-2} \\
\text { (no.) }\end{array}$ & $\begin{array}{c}\text { 1000-grain wt. } \\
\text { (g) }\end{array}$ & $\begin{array}{c}\text { Grain } \\
\text { yield (t ha- } \\
1 \text { ) }\end{array}$ \\
\hline $\mathrm{V}_{1} \mathrm{~S}_{1}$ & 71.00 & 92.27 & 38.78 & 190.3 & 36.13 & 2.671 \\
\hline$V_{1} S_{2}$ & 74.00 & 92.20 & 40.89 & 262.7 & 38.77 & 4.162 \\
\hline $\mathrm{V}_{1} \mathrm{~S}_{3}$ & 78.00 & 84.77 & 40.67 & 226.3 & 35.10 & 3.226 \\
\hline $\mathrm{V}_{2} \mathrm{~S}_{1}$ & 70.33 & 89.33 & 40.33 & 228.0 & 38.80 & 3.556 \\
\hline $\mathrm{V}_{2} \mathrm{~S}_{2}$ & 70.00 & 82.40 & 42.78 & 221.0 & 43.67 & 4.128 \\
\hline $\mathrm{V}_{2} \mathrm{~S}_{3}$ & 78.67 & 86.00 & 38.00 & 200.3 & 40.27 & 3.066 \\
\hline $\mathrm{V}_{3} \mathrm{~S}_{1}$ & 67.00 & 91.00 & 33.78 & 224.0 & 42.10 & 3.173 \\
\hline $\mathrm{V}_{3} \mathrm{~S}_{2}$ & 70.33 & 86.53 & 41.00 & 255.7 & 44.07 & 4.605 \\
\hline $\mathrm{V}_{3} \mathrm{~S}_{3}$ & 76.67 & 83.57 & 37.89 & 224.0 & 34.87 & 2.944 \\
\hline $\mathrm{V}_{4} \mathrm{~S}_{1}$ & 69.00 & 88.33 & 39.89 & 196.0 & 33.30 & 2.601 \\
\hline $\mathrm{V}_{4} \mathrm{~S}_{2}$ & 72.33 & 84.93 & 44.78 & 231.3 & 43.83 & 4.531 \\
\hline $\mathrm{V}_{4} \mathrm{~S}_{3}$ & 75.33 & 83.20 & 34.78 & 211.7 & 41.93 & 3.085 \\
\hline $\operatorname{LSD}_{(0.05)}$ & 1.78 & 1.73 & 3.47 & 21.4 & 4.83 & 0.46 \\
\hline CV (\%) & 1.44 & 1.17 & 5.20 & 5.68 & 7.24 & 7.94 \\
\hline
\end{tabular}

Yield and yield components of wheat, significantly reduced under late seeding conditions, were also observed by Tyagi et al. (2003), Munjal et al. (2004). It might be due to lower dry matter accumulations in grain due to prevailing high temperature at grain filling period. The lower grain yield due to late sowing of wheat compared to optimum sowing also observed by Islam et al. (1993), Bhatta et al. (1994) and Gul et al. (2012).

\section{Conclusion}

BARI Gom-26 sown at 01 December performed better in relation to grain growth to produce heavier grain. At 01 December sowing, all the four wheat variety produced maximum grain yield. Among the varieties, BARI Gom-25 yielded better than others.

\section{References}


103

Grain Growth and Yield of Wheat as Influenced by Variety and Sowing Date

AIS (Agriculture Information Service) 2013.. Ministry of Agriculture. Govt. of the people's Republic of Bangladesh. Khamarbari, Farmgate, Dhaka.

Asseng, S., F. Ewert, P. Martre, R. P., Rötter, D. B. Lobell, D. Cammarano. 2015. Rising temperature reduce global wheat production. Nature Climate change 5: 143- 147.

BBS (Bangladesh Bureau of Statistics). 2013. Statistical year book of Bangladesh. Statistical Division, Ministry of Planning. Govt, of the people's Republic of Bangladesh, Dhaka.

Bhatta, M. R., J. E. Hernandez and J. S. Lales. 1994. Possibilities of selecting wheats with fast grain filling rate for warmer areas. In: D.A. Saunders and G.P. Hatel (ed.) Wheat in Heatstressed Environments: Irrigated. Dry Areas and Rice-wheat Farming System. CIMMYT. Mexico D.F. p. 375-378.

FAO (Food and Agricultural Organization). 2009. Production Year Book. An Appraisal of Seed Biology and the Yield of Grain Crops. Cab. International. p. 112-121.

FRG 2012. Fertilizer Recommendation Guide, 2012. Bangladesh Agricultural Research Council (BARC), New Airport Road, Farmgate, Dhaka 1215.

Fisher, R. A. 2007. Understanding the physiological basis of yield potential in wheat. J. Agric. Sci. 145: 99-113.

Gomez, K. A. and A. A. Gomez. 1984. Statistical Procedure for Agricultural Research ( ${ }^{\text {nd }}$ edn.). Int. Rice Res. Inst. andWilley, New York pp. 28-192.

Gul, H., B. Saeed, A. Z. Khan, U. Latif, K. Ali, J. Rehman and S. Rehman.2012. Yield and yield contributing traits of wheat cultivars in relation with planting dates and nitrogen fertilization. ARPN J. Agril. Biol. Sci. 7(6):386- 395.

Gupta, A., M. Gupta and B. R. Bazaya. 2010. Effect of sowing dates and genotypes on growth and yield of durum wheat (Triticum durum L). J. Res. SKUAST 9: 164-168.

Hasan, M. A. and Ahmed J U. (2005). Kernel growth physiology of wheat under late planting heat stress, J. Natl.. Sci. Foundn. Sri Lanka. 33(3):193-204.

Hussain, A. and J.A. Teixeira da Silva. 2012. Phenology, growth and yield of three wheat (Triticum aestivum L.) varieties as affected by high temperature stress. Not. Sci. Biol. 4(3):97-109.

Islam A.S. 2009. Analyzing changes of temperature over Bangladesh due to global warming using historic data. Young Scientists of Asia Conclave, Jawaharlal Nehru Centre for Advanced Scientific Research (JNCASR), 15-17 January, Jakkur, Bangalore.

Karim, M. A., A. Hamid and S. Rahman. 2000. Grain growth and yield performance of wheat under subtropical countries: II. Effect of water stress at reproductive stage. Cereal Res. Comm. 28: 101-107.

Karmakar, S. and M. L. Shresth. 2000. Recent Climatic Changes in Bangladesh. SMRC No.4. SAARC Meteorological Research Centre, Agargaon, Dhaka, Bangladesh

Munjal, R., S. S. Dhanda, R. K. Rana and I. Singh. 2004. Cell membrane thermo stability as an indicator of heat tolerance at seedling stage in bread wheat. Natl. J. PI. Imp. 6(2): 133135.

Qasim, M., M. Qamer, Faridullah and M. Alam. 2008. Sowing dates effect on yield and yield components of different wheat varieties. J. Agril. Res. 46: 304-315.

OECD 2003. Rising food prices: Causes and consequences. 9 p. Available online: http://www.oecd.org/dataoecd/54/42/40847088. pdf [Accessed on the 20 January 2009]. 
Uddin et al.

Poulton, P. L. and M. H. Rawson(2011). Physical constraints to cropping in southern Bangladesh, 256 p. In: Rawson HM (Ed.).Sustainable Intensification of Rabi Cropping in Southern Bangladesh Using Wheat and Mungbean, ACIAR Technical Reports No. 78. Australian Centre for International Agricultural Research, Canberra.

Shirpurkar, G. N., N. V. Kashid and A. A. Pisal. 2007. Effect of different sowing dates and varieties on yield and yield attributes of wheat. Agril. Sci. Digest. 27: 68-70.

Stone, P.J. and Nicolas, M.E. (1995). Effect of timing of heat stress during grain filling on two wheat varieties differing in heat tolerance.1. Grain growth. Aust. J. Pl. Physiol. 22(6): 927-934

Tahir, M., A. Ali, M.A. Nadeem, A. Hussain and F. Khalif (2009). Effect of different sowing dates on growth and yield of wheat (Triticum aestivum L.) varieties in district Jhang, Pakistan. Pak. J. Life Soc. Sci. 7(1):66-69.

Tewolde, H., C. J. Fernandez and C. A. Erickson. 2006. Wheat cultivars adapted to post-heading high temperature stress. J. Agron. Crop Sci. 192: 111-120.

Tyagi, P. K., R. K. Pannu, K. D. Sharma, B. D. Chaudhary and D. P. Singh. 2003. Effect of sowing time on performance of wheat genotypes. Annals Biol. 19(2): 119-122. 